\title{
Native Cyclodextrins and Their Derivatives as Potential Additives for Food Packaging: A Review
}

\author{
Tarsila R. Arruda (D), Clara S. Marques*(D) and Nilda F. F. Soares
}

Food Packaging Laboratory, Food Technology Department, Federal University of Viçosa, Viçosa 36570-900, Brazil; tarsila.arruda@ufv.br (T.R.A.); nfsoares@ufv.br (N.F.F.S.)

* Correspondence: supraniclara@gmail.com

Citation: Arruda, T.R.; Marques, C.S.; Soares, N.F.F. Native Cyclodextrins and Their Derivatives as Potential Additives for Food Packaging: A Review. Polysaccharides 2021, 2 , 825-842. https://doi.org/10.3390/ polysaccharides 2040050

Academic Editors: Cédric Delattre, Paolina Lukova and Guillaume Pierre

Received: 29 September 2021

Accepted: 26 October 2021

Published: 2 November 2021

Publisher's Note: MDPI stays neutral with regard to jurisdictional claims in published maps and institutional affiliations.

Copyright: (c) 2021 by the authors. Licensee MDPI, Basel, Switzerland. This article is an open access article distributed under the terms and conditions of the Creative Commons Attribution (CC BY) license (https:/ / creativecommons.org/licenses/by/ $4.0 /)$.

\begin{abstract}
Cyclodextrins (CDs) have been used by the pharmaceutical and food industries since the 1970s. Their cavities allow the accommodation of several hydrophobic molecules, leading to the formation of inclusion complexes (ICs) increasing the guest molecules' stability, allowing their controlled release, enhancing their water solubility and biodisponibility. Due to these, CDs and their ICs have been proposed to be used as potential allies in food packaging, especially in active packaging. In this review, we present the many ways in which the CDs can be applied in food packaging, being incorporated into the polymer matrix or as a constituent of sachets and/or pads aiming for food preservation, as well as the diverse polymer matrices investigated. The different types of CDs, natives and derivatives, and the several types of compounds that can be used as guest molecules are also discussed.
\end{abstract}

Keywords: polymers; food packaging; active packaging; cyclodextrins; natural preservatives; inclusion complex

\section{Introduction}

Discovered in 1891 from starch degradation by the action of the microorganism Bacillus amylobacter, cyclodextrins (CDs) were patented for the first time almost sixty years later as an important agent for obtaining drug inclusion complexes (ICs) [1]. However, it was only in the 1970s, when toxicological studies ensured their innocuousness, that their use by the pharmaceutical industry in fact began, being used to this day in the elaboration of drugs, cosmetics, and hygiene products [2]. CDs have become an essential ingredient for these areas as they act as carriers of substances of interest, promote the controlled release of drugs, and increase the water solubility of poorly soluble compounds, enhancing their biodisponibility [3-5].

Biotechnological advances that occurred between the 1970s and 1980s allowed the large-scale production of more purified CDs, increasing the interest in their use by sectors other than Pharmaceutical and Biomedical. In food-related areas, for example, their use was firstly authorized in the late 1970s, in Japan, in the production of spices, chocolates, teas, among other products. However, it was only in the early 2000s that the CDs entered the list of substances generally recognized as safe (GRAS) from the Food and Drug Administration (FDA), being recognized as a food additive [1,6]. Nowadays, enzymes involved in the formation of cyclodextrins from starch can be found in the market, as well as several types of cyclodextrins and their inclusion complexes for both pharmaceutics and food usage [7-10].

In addition to the aforementioned properties, CDs are also able to form complexes with a wide range of substances, from small molecules of low molecular weight to bigger compounds, depending on the type of CD used [11-13]. Besides, they can increase the stability of the guest molecules against external factors such as temperature, light, and oxygen $[14,15]$. Due to these, the CDs have come to be considered potential additives for packaging with active properties, especially when the active compound can be easily 
degraded or oxidized [16]. Since the production of packaging generally involves the use of high temperatures for polymers to melt, the use of several active compounds becomes unfeasible due to their thermal instability, an obstacle that can be overcome when performing the complexation of these substances with CDs. In this context, this review aims to discuss CDs as promising additives in food packaging. The different types of CDs, the mechanisms involved in the complexation process, and the incorporation of CDs into polymeric matrices aiming to obtain packaging with varied properties will be presented and discussed.

\section{Natural and Modified Cyclodextrins}

\subsection{Structure, General Characteristic and Properties of Interest}

CDs are cyclic molecules composed of glucose subunits linked through $\alpha$-1,4-glycosidic bonds. Their classification is made according to the number of glucopyranoses units, being $\alpha-C D$ (6 units), $\beta-C D$ ( 7 units), and $\gamma-C D$ (8 units) the three native or "parent" CDs [17]. CDs containing 9 or more glucose units in their structure are also described in the literature and have been conventionally named large ring CDs [18]. The cyclic conformation and molecular arrangement of the hydroxyl groups give the CDs a toroidal shape, similar to a hollow cone, with an external face of polar nature due to the presence of hydroxyl groups, and a non-polar cavity, in which hydrophobic compounds can be accommodated [2].

One of the main characteristics of CDs of importance for application in food-related areas is their water solubility. Native CDs have a certain solubility in water, $\gamma$-CD being the most soluble of the three $\left(249 \mathrm{mg} \cdot \mathrm{mL}^{-1}\right)$ and $\beta-\mathrm{CD}$ the least soluble $\left(18.5 \mathrm{mg} \cdot \mathrm{mL}^{-1}\right)$ [19]. Such functionality allows, by forming ICs with nonpolar compounds, that the solubility of the guest molecule when compared to the pristine substance to be increased, consequently enhancing its bioavailability in the medium. In general, the formation of inclusion complexes with CDs also allows the controlled release of the compound of interest and protects unstable substances from external factors as well as from undesirable interactions that may occur in the environment, being an interesting alternative for the food packaging industry $[14,19,20]$. The main properties of the native CDs, as well as their commercial names, are briefly described in Table 1.

Table 1. Main properties of $\alpha-, \beta-$, and $\gamma$-cyclodextrins.

\begin{tabular}{|c|c|c|c|}
\hline Property & $\alpha$-Cyclodextrin & $\beta$-Cyclodextrin & $\gamma$-Cyclodextrin \\
\hline $\begin{array}{c}\text { Commercial name on the } \\
\text { Market }\end{array}$ & $\begin{array}{c}\text { Cavamax }^{\circledR} \text { W6 [8], Trappsol } \\
\text { Native Alpha [10] }\end{array}$ & $\begin{array}{l}\text { Cavamax }^{\circledR} \text { W7 [8], Kleptose }{ }^{\circledR} \\
\text { [9], Trappsol }{ }^{\circledR} \text { Native Beta [10] }\end{array}$ & $\begin{array}{c}\text { Cavamax }^{\circledR} \text { W8 [8], Trappsol } \\
\text { Native Gamma [10] }\end{array}$ \\
\hline $\begin{array}{l}\text { Functions on Markets } \\
\text { products }\end{array}$ & $\begin{array}{l}\text { Solubilizer, stabilizer, delivery } \\
\text { of drugs }[8,10]\end{array}$ & $\begin{array}{c}\text { Solubilizer, stabilizer, delivery } \\
\text { of drugs and taste-masking } \\
\text { agent }[9,10]\end{array}$ & $\begin{array}{c}\text { Solubilizer, stabilizer, } \\
\text { stabilization enhancer, } \\
\text { delivery of drugs }[8,10]\end{array}$ \\
\hline Number of glucose subunits & 6 & 7 & 8 \\
\hline Molar mass $\left(\mathrm{g} \cdot \mathrm{mol}^{-1}\right)$ & 972 & 1135 & 1297 \\
\hline External size (nm) & $1.4-1.5[19]$ & $1.5-1.6[19]$ & $1.7-1.8[19]$ \\
\hline Internal diameter (nm) & $0.47-0.52[21]$ & $0.60-0.80[21]$ & $0.75-1.00[21]$ \\
\hline $\begin{array}{l}\text { Water solubility at } 25^{\circ} \mathrm{C} \\
\left(\mathrm{mg} \cdot \mathrm{mL}^{-1}\right)\end{array}$ & $145[21]$ & $18.5[21]$ & $232[21]$ \\
\hline Solubility in organic solvents & $\begin{array}{l}\text { Insoluble in chloroform, } \\
\text { isopropanol, acetone, ethanol, } \\
\text { glycerin, methanol, and ethyl } \\
\text { ether. Soluble in propylene } \\
\text { glycol }\left(10 \mathrm{mg} \cdot \mathrm{mL}^{-1}\right) \text {, } \\
\text { dimethyl sulfoxide } \\
\left(20 \mathrm{mg} \cdot \mathrm{mL}^{-1}\right) \text {, and } \\
\text { dimethylformamide } \\
\left(540 \mathrm{mg} \cdot \mathrm{mL}^{-1}\right)[21]\end{array}$ & $\begin{array}{l}\text { Insoluble in chloroform, } \\
\text { isopropanol, acetone, ethanol, } \\
\text { methanol, and ethyl ether. } \\
\text { Soluble in dimethyl sulfoxide } \\
\left(350 \mathrm{mg} \cdot \mathrm{mL}^{-1}\right) \text {, ethylene } \\
\text { glycol }\left(210 \mathrm{mg} \cdot \mathrm{mL}^{-1}\right) \text {, } \\
\text { dimethylformamide } \\
\left(320 \mathrm{mg} \cdot \mathrm{mL}^{-1}\right) \text {, and glycerin } \\
\left(43 \mathrm{mg} \cdot \mathrm{mL}^{-1}\right)[21]\end{array}$ & $\begin{array}{l}\text { Insoluble in chloroform and } \\
\text { ethyl ether. Soluble } \\
\left(>1 \mathrm{mg} \cdot \mathrm{mL}^{-1}\right) \text { in isopropanol, } \\
\text { acetone, ethanol, and } \\
\text { methanol [21] }\end{array}$ \\
\hline
\end{tabular}




\section{2. $\alpha-C D$}

$\alpha$-CDs are constituted of 6 subunits of D-glucopyranoses, being obtained enzymatically from starch and its derivatives, and, among the native CDs, they are the ones with the smallest internal diameter, ranging from 0.47 to $0.52 \mathrm{~nm}$ [22]. As functional properties, these molecules have moderate solubility in water (almost eight times greater than that presented by $\beta$-CDs, but less than $\gamma$-CDs), relative thermal stability, stability under extreme conditions of $\mathrm{pH}$ (alkaline and acidic solutions), and slightly pronounced sensory characteristics (imperceptible taste and odor) [23]. The molecule was granted GRAS status by the FDA in 2004 (GRN 000155), and in 2016, the agency waived the requirement for pre-marketing approval, provided it meets the maximum level of $3 \%(w / w)$ in processed foods and $1.05 \%$ in beverages [24].

Among the applications of $\alpha$-CDs in the Food Industry, it is worth mentioning their role as an emulsifier agent, as a functional ingredient, and as a carrier and stabilizing agent for different molecules, such as hormones and flavorings [25-27]. Furthermore, its ability to act as a host for smaller bioactive components opens doors for its use in the development of active packaging. Besides, when we talk about sustainable packaging, the water solubility of $\alpha$-CDs can be an advantage since several biopolymers investigated are dispersible in water [28-31]. In addition, the chemical structure of $\alpha$-CDs makes their hydrolysis impossible by human saliva, as well as pancreatic amylases. Therefore, this characteristic gives a probiotic character to these substances and a possible application as dietary fibers [32].

\section{3. $\beta-C D$}

Among the three native types of CDs, $\beta-C D$ is the most used and studied due its low cost when compared to the other two CDs, its good complexation efficiency, and the size of its cavity, which, in practice, allows a good accommodation of a large amount of molecules $[14,19,33-40]$. About $90 \%$ of the CDs produced and consumed are $\beta$-CDs [41]. In addition, the internal diameter of the $\beta$-CD's cavity makes it popular in the pharmaceutical industry since it is suitable for the inclusion of several substances with a molar mass between $200-800 \mathrm{~g} \cdot \mathrm{mol}^{-1}$ [22]. However, the $\beta$-CD low water solubility is a disadvantage and the reason why $\mathrm{CD}$ derivatives were developed with various substituents (methyl, carboxymethyl, hydroxypropyl, sulfobutyl, among others) [42]. Hydroxypropyl- $\beta-C D$ and randomly methylated $\beta-C D$, for example, have water solubility greater than $600 \mathrm{mg} \cdot \mathrm{mL}^{-1}$, a much more considerable value than the solubility of the native $\beta-\mathrm{CD}$ [2].

\section{4. $\gamma-C D$}

The last native CD to be discovered (1935), $\gamma$-CD consists of 8 subunits of glucopyranose, with a larger internal diameter among the three native molecules [22,43]. Due to its high solubility in water, $\gamma$-CD can be used as a solubilizing agent by carrying highly hydrophobic molecules [44,45]. Considering the pharmaceutical industry, several inclusion complexes $\gamma$-CD-based containing bioactive molecules tend to form aggregated structures in aqueous solutions, indicating potential activity as a drug-containing vehicle $[44,46]$. Other applications include the production of cosmetics (e.g., increased stability and solubility of components) [47]; chemical industry (e.g., separation of isomers, functional groups, homologous and enantiomers) [48]; textile industry (e.g., restoration of colors, good completion of cotton-based materials) [49]; and agriculture (e.g., immobilization of fragrances and repellents, reduction of the risk of contact with chemicals, increased effect of pesticides) [50].

\subsection{Large Ring CDs}

CDs composed of more than 8 units of glucopyranoses are known as large rings CDs and were first described in 1948. Compared to the other CDs, fewer studies have been conducted on this broad group of molecules [1]. In fact, some CDs can have more than 100 glucose units, which can be obtained through the use of specific enzymes or very 
specific conditions of temperature and incubation time [51]. The difficulties associated with their purification and very low yield are barriers to their use on a larger scale [52]. More recently, however, some works have been described in the literature seeking alternatives for the production and purification of large ring CDs, also aiming for their application by the chemical, pharmaceutical, and food industries [52].

\subsection{Modified CDs}

Although it has been discussed in the literature that the complexation with CDs can increase the guest compound solubility in water, the native CDs present limited solubilization in the solvent. $\beta-C D$, for example, the most affordable and the most suitable for the inclusion of substances due to its cavity volume, is also the least soluble of the three natives CDs, which is a disadvantage. In this regard, synthetic derivatives were developed from the substitution of hydroxyl groups in the structure of the original CD, conferring different properties and improving the molecule solubility in water, consequently, opening a wider range of applications [2,4,42,53].

The CDs' derivatives can be classified into three groups: anionic, cationic, and nonionic, depending on the inserted group [54]. As an example of anionic derivatives, we can cite the sulfobutylether- $\beta-C D$ and the per(6-carboxylate)-CD, which have potential in pharmaceutical research for controlled released and advanced targeted delivery of drugs [55]. 2-Hydroxypropyl- $\beta-\mathrm{CD}(\mathrm{HP}-\beta-\mathrm{CD})$ is an example of a non-ionic structure largely studied both in pharmaceutical and food-related areas, and permethylated propylenediamine- $\beta-C D$ is one of the synthesized cationic derivatives [54,56,57].

\section{Preparation of Inclusion Complexes}

The nonpolar cavity of CDs is a favorable environment for the accommodation of molecules of hydrophobic nature and varied sizes, molecular weight, and geometry (Figure 1). In the literature, there are several reports concerning the complexation of native or derivatives CDs involving both solid or liquid compounds, diverse drugs $[46,53,55,56]$, essential oils (EOs) and their constituents [12,20,34,35], flavoring agents and pigments [4,5,58,59], as well as natural antimicrobials $[12,35,40]$. In Table 2 , examples of ICs obtained from the complexation of the different types of CDs with several molecules are displayed.

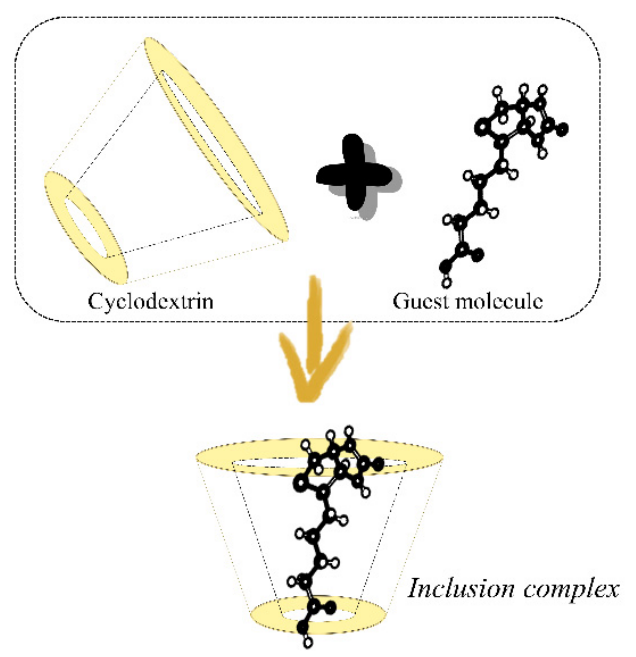

Figure 1. Representation of the entrapment of a guest molecule in the cyclodextrin's cavity. 
Table 2. Inclusion complexes obtained with several types of guest molecules and cyclodextrins (CDs).

\begin{tabular}{|c|c|c|c|}
\hline CD & Guest Molecule & Main Effects of Complexation & Reference \\
\hline $\mathrm{HP}-\gamma-\mathrm{CD}$ & Ferulic acid & $\begin{array}{l}\text { Accelerating dissolution of } \\
\text { oral-introduced medicinal products }\end{array}$ & {$[60]$} \\
\hline $\mathrm{HP}-\beta-\mathrm{CD}$ & Glabridin & $\begin{array}{l}\text { Increased water solubility and } \\
\text { bioactivity }\end{array}$ & [61] \\
\hline$\beta-C D$ & Basil and Pimenta dioica EOs & Increased the EOs thermal stability & [38] \\
\hline$\alpha-C D$ & Moringin & $\begin{array}{c}\text { Increased water solubility and } \\
\text { verification of anti-inflammatory effect }\end{array}$ & [62] \\
\hline $\mathrm{HP}-\gamma-$ and $\mathrm{HP}-\beta-\mathrm{CD}$ & Cinnamaldehyde & $\begin{array}{l}\text { Increased thermal stability, increased } \\
\text { solubility and dissolution in water, } \\
\text { maintenance of antimicrobial activity } \\
\text { against Escherichia coli }\end{array}$ & [63] \\
\hline $\mathrm{HP}-\gamma-$ and $\mathrm{HP}-\beta-\mathrm{CD}$ & Curcumin & $\begin{array}{l}\text { Increased solubility in water, which } \\
\text { promoted higher antioxidant activity }\end{array}$ & [64] \\
\hline $\begin{array}{l}\text { HP- } \gamma-, \mathrm{HP}-\beta-\text {, and } \\
\text { methyl- } \beta-\mathrm{CD}(\mathrm{M}-\beta-\mathrm{CD})\end{array}$ & Thymol & $\begin{array}{l}\text { Reduced volatility, increased water } \\
\text { solubility, rapid disintegration in water, } \\
\text { increased thermal stability }\end{array}$ & [65] \\
\hline $\begin{array}{l}\alpha-, \beta-, \mathrm{HP}-\beta-, \gamma-C D, \text { randomly } \\
\text { methylated CD (RAMEB), and } \\
\text { low methylated CD }\end{array}$ & Estragole & $\begin{array}{l}\text { Higher photostability and antioxidant } \\
\text { activity, controlled release of the guest } \\
\text { molecule }\end{array}$ & [20] \\
\hline$\beta$ - and $\gamma-C D$ & Rosmarinic acid & $\begin{array}{l}\text { Increased stability, solubility, } \\
\text { bioavailability, antioxidant and } \\
\text { anti-inflammatory activities }\end{array}$ & [66] \\
\hline$\gamma-\mathrm{CD}$ & Quercetin & $\begin{array}{l}\text { Increased water solubility of the guest } \\
\text { molecule stability }\end{array}$ & [67] \\
\hline$\alpha-C D$ & Allyl sulfide & Controlled release of the guest molecule & {$[68]$} \\
\hline $\begin{array}{c}\mathrm{HP}-\beta-\mathrm{CD}, \mathrm{HP}-\gamma-\mathrm{CD} \text { and } \\
\mathrm{M}-\beta-\mathrm{CD}\end{array}$ & Linalool & $\begin{array}{l}\text { Increased thermal stability, rapid } \\
\text { dissolution and controlled release of } \\
\text { the active compound, antimicrobial } \\
\text { activity against Gram-positive and } \\
\text { Gram-negative bacteria }\end{array}$ & [69] \\
\hline$\beta-C D$ & Garlic EO & Thermal protection & [14] \\
\hline
\end{tabular}

There are many methods for preparing inclusion complexes and the choice of each one will depend on the cost of the process, yield, processing time, and equipment availability [19]. The kneading method, for example, is a low-cost method that provides the obtainment of high yield ICs and, compared to the others, is relatively simple for scaling up [38,70-72]. The co-precipitation is another method largely used in CDs' studies $[37,39,73,74]$, and the freeze-drying technique, although more expensive due to lyophilization, is rather widespread $[4,14,38,70]$. Other methods used for producing ICs, such as supercritical antisolvent precipitation [53,75] and spray drying [68], are discussed in the literature.

Regardless of the method used, the formation of inclusion complexes is a spontaneous process, guided either by the difference in enthalpy, or entropy, or by both, and which involves the exit of water molecules from the cavity and the entry of the guest molecule [76,77]. Since the CDs' hydroxyl groups are orientated outwards, their cavities constitute a more hydrophobic environment, and the water molecules that are naturally present in there are highly energetic $[21,78]$. Their replacement by more apolar compounds is, then, thermodynamically favored and an enthalpic driving force of the complexation process [78]. It is discussed that several other driving forces are also involved in the complexation of CDs and guest molecules, each one having an important role in stabilizing 
the inclusion complexes. Electrostatic interactions, hydrogen bonding, van der Waal's interactions, and dipole moment have been proposed by many studies $[52,70,74,76,79,80]$.

Santos et al. investigated the complexation of carvacrol, the major compound of oregano EO, with $\beta-\mathrm{CD}$. The thermodynamic parameters obtained by the authors were an indication that the formation of IC was driven by hydrophobic interactions due to the replacement of high-energy water molecules in the CD cavity by the apolar compound, as well as van der Waals interactions and hydrogen bonds [70]. Similarly, Tao et al., when studying the IC formation between $\beta-\mathrm{CD}$ and thymol, verified that the Gibbs energy was, in fact, negative $(\Delta \mathrm{G}<0)$, indicating a spontaneous process, and that hydrophobic interaction, hydrogen bonds, and van der Waals intermolecular interactions were likely involved [81].

\section{Incorporation of CDs/ICs into Polymer Matrices}

CDs and their ICs have been studied with several polymers aiming the preparation of different kinds of packaging for food preservation, from conventional petroleum-based plastics $[39,82,83]$ to sustainable ones $[12,35,37,40,59]$. In Table 3 , examples of CDs/ICs, as well as the support polymer matrix of choice and the main goal of the elaborated packaging are summarized.

Table 3. Cyclodextrins (CDs) in food packaging.

\begin{tabular}{|c|c|c|c|c|}
\hline CD & Guest Molecule & Packaging Polymer & Purpose of CD/IC in Packaging & Reference \\
\hline \multicolumn{5}{|c|}{ As inclusion complex } \\
\hline $\mathrm{HP}-\beta-\mathrm{CD}$ & Gallic acid & $\begin{array}{l}\text { Polylactic acid (PLA) } \\
\text { nanofibers }\end{array}$ & $\begin{array}{l}\text { Promote the controlled release of the active } \\
\text { compound }\end{array}$ & [84] \\
\hline$\beta-C D$ & PLA & PLA & Increase the thermal stability of PLA films & [85] \\
\hline$\beta-C D$ & Cinnamon EO & PLA nanofibers & $\begin{array}{l}\text { Manufacture an antimicrobial film with increased } \\
\text { thermal stability of the bioactive molecule }\end{array}$ & [86] \\
\hline$\alpha-$ and $\gamma-\mathrm{CD}$ & Oregano EO & $\begin{array}{c}\text { Poly (3-hydroxybutyrate-co- } \\
\text { 3-hydroxy valerate) } \\
\text { (PHBV) }\end{array}$ & $\begin{array}{l}\text { Increase thermal stability of the bioactive } \\
\text { compound for film making at high temperatures }\end{array}$ & [72] \\
\hline$\beta-C D$ & Cinnamaldehyde & PLA & $\begin{array}{l}\text { Improve mechanical and barrier properties, in } \\
\text { addition to promote the controlled release of the } \\
\text { bioactive molecule (active packaging) }\end{array}$ & [59] \\
\hline$\beta-C D$ & Eugenol and carvacrol & Whey protein & $\begin{array}{c}\text { Promote the controlled release of antimicrobial } \\
\text { bioactive compounds in edible films }\end{array}$ & [87] \\
\hline $\begin{array}{l}\text { Carboxymethyl- } \\
\beta-C D\end{array}$ & Curcumin & $\begin{array}{l}\text { Polyethylene-terephthalate } \\
\text { (PET) }\end{array}$ & $\begin{array}{l}\text { Develop an antimicrobial film with } \\
\text { controlled release }\end{array}$ & [83] \\
\hline $\mathrm{HP}-\beta-\mathrm{CD}$ & Berberine & Gelatin & $\begin{array}{l}\text { Preparation of antibacterial films with } \\
\text { anti-ultraviolet properties (increased solubility and } \\
\text { thermal stability of the active compound) }\end{array}$ & [88] \\
\hline$\beta-C D$ & D-limonene & $\begin{array}{l}\text { Poly (butylene-succinate) } \\
\text { (PBS) }\end{array}$ & $\begin{array}{l}\text { Thermal stabilization of the active compound and } \\
\text { improvement of the thermal properties of PBS films }\end{array}$ & [89] \\
\hline$\beta-C D$ & Allyl isothyocianate & Cellulose acetate & Promote the controlled release of the active agent & [40] \\
\hline \multicolumn{5}{|c|}{ As a polymer blend component } \\
\hline$\beta-\mathrm{CD}$ & Cinnamon EO & $\begin{array}{l}\text { Polyvinyl alcohol (PVA) } \\
\text { (nanofibers) }\end{array}$ & $\begin{array}{l}\text { Control the EO odor and ensure a more controlled } \\
\text { release to obtain antimicrobial active packaging }\end{array}$ & [33] \\
\hline$\beta-C D$ & - & Zein & Cholesterol absorption & [90] \\
\hline$\beta-C D$ & Allyl isothyocianate & $\begin{array}{l}\text { Low-density polyethylene } \\
\text { (LDPE) }\end{array}$ & Promote the controlled release of the active agent & [82] \\
\hline $\begin{array}{l}\text { (2-carboxyethyl)- } \\
\beta \text {-CD }\end{array}$ & - & $\begin{array}{c}\text { Chitosan and PLLA (loaded } \\
\text { with ZnO } \\
\text { nanoparticles-multilayer) }\end{array}$ & Improve PLLA functionality as packaging material & [91] \\
\hline$\beta-C D$ & $\begin{array}{l}\text { Cinnamon and oregano } \\
\text { EOs }\end{array}$ & $\begin{array}{l}\text { Chitosan and PVA } \\
\text { (multilayer) }\end{array}$ & $\begin{array}{c}\text { Improve the release of EOs and prepare films with } \\
\text { antifungal activity }\end{array}$ & [92] \\
\hline$\beta-C D$ & - & $\begin{array}{l}\text { Ethylene-vinyl alcohol } \\
\text { (EVOH) }\end{array}$ & $\begin{array}{c}\text { Promote changes in the morphological, thermal and } \\
\text { barrier properties of EVOH }\end{array}$ & [93] \\
\hline
\end{tabular}


Currently, numerous techniques have been described as strategies for incorporation of $\mathrm{CDs} / \mathrm{ICs}$ into polymer matrices. They can be directly blended with the polymer matrices for further development of composite films, which is a simple and common method employed for food packaging manufacturing [94]. Along with this, other methods such as extrusion $[39,82]$, casting $[12,40]$, and electrospinning $[65,67,72]$ can be mentioned for application of CDs/ICs into packaging systems, aiming further industrial use. Examples of these techniques and their principles are schematized in Figure 2.

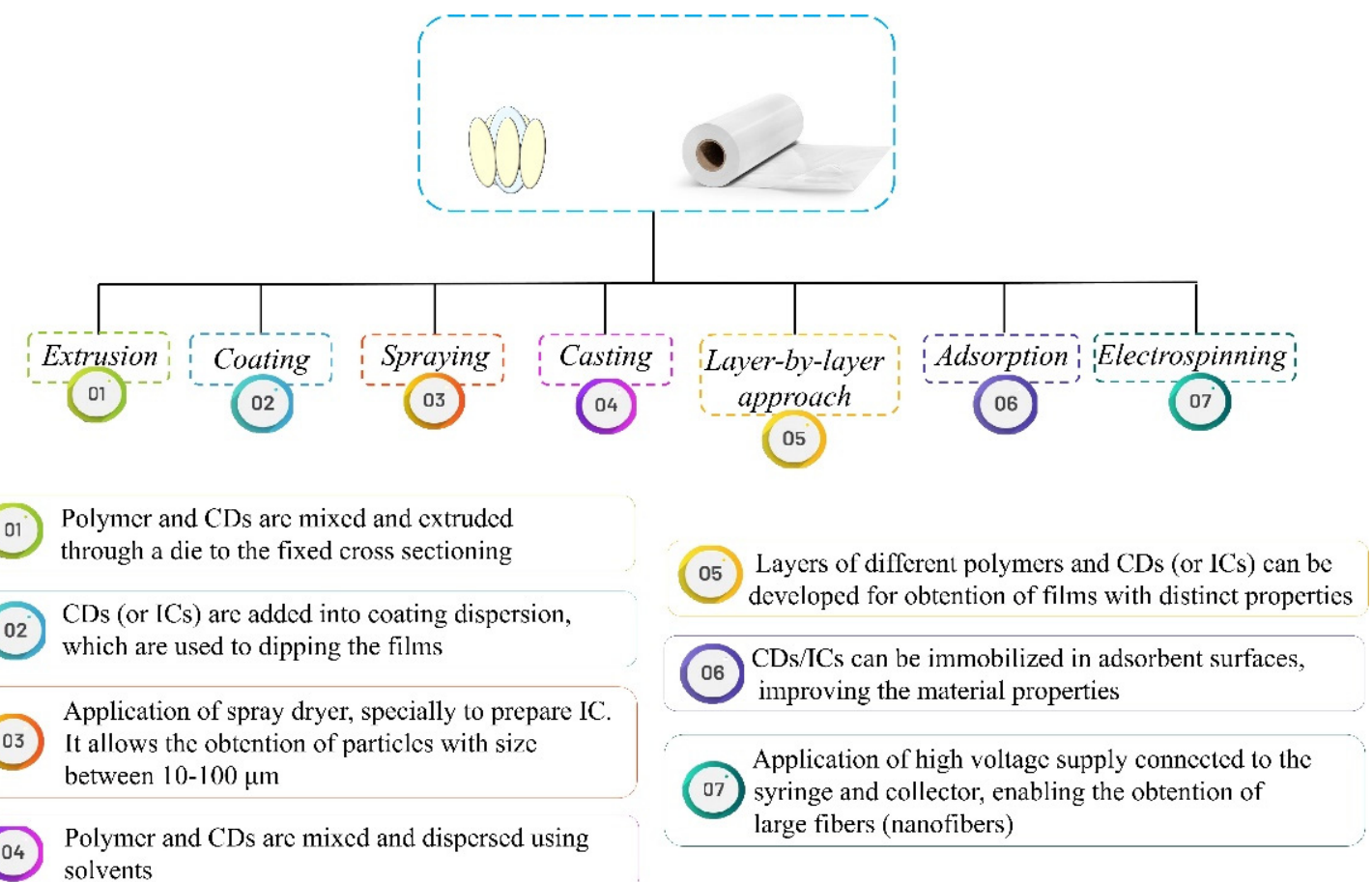

Figure 2. Different methods aiming the obtainment of films containing cyclodextrins (CDs) or their inclusion complexes (ICs).

\section{Active Packaging for Food Preservation}

Four main functions are attributed to packaging: containment, protection, convenience, and communication with the consumers [95]. Such characteristics must be inherent to any type of packaging. However, in a more specific context for the food industry and conventionally used packaging, there is still an increasing demand for new technologies to obtain better performance in reducing losses and prolonging the shelf life of foods [96]. This demand resulted in the development of active packaging, a new concept of food packaging that can be described as "packaging that deliberately incorporates components that can release or absorb substances into either the packaged food or the environment surrounding the food" [97].

Plastic materials have been widely used in the manufacture of food packaging, mainly due to attributes such as relative stability, ease of production, low cost, and barrier properties [98]. However, these materials are commonly processed at high temperatures, usually between $100{ }^{\circ} \mathrm{C}$ and $200^{\circ} \mathrm{C}$ (above the polymer's melting point). In the context of active packaging, such conditions are quite aggressive since they may significantly affect the bioactive components incorporated into the packaging material. Volatilization and thermal degradation can culminate in the bioactive substances' loss [16]. As carrier agents, CDs can reduce or even prevent the loss of efficiency of bioactive ingredients by forming inclusion complexes to be incorporated into the polymer matrix $[14,38]$. In addition to the greater stability conferred by the complexation process, the formation of ICs can also confer greater homogeneity to the system when the bioactive components of interest are not directly compatible with the polymer. 


\subsection{ICs as Active Compounds Carriers}

The incorporation of inclusion complexes between bioactive molecules and CDs is an interesting approach for the development of active packaging systems, which can allow the obtention of different films with improved active properties. Aytac et al. [84] investigated ICs formed by gallic acid and HP- $\beta$-CD into poly nanofibers (lactic acid) and evaluated the release profiles of the active component under different conditions (water, $10 \%$ ethanol, and $95 \%$ ethanol). The complexation with HP- $\beta-\mathrm{CD}$ promoted an increase in the solubility of the active ingredient, enhancing its release rate in the media containing $10 \%$ of ethanol. The authors also verified a high antioxidant activity for the nanofibers produced. Therefore, the obtained active film could be applicable as packaging material for food preservation.

Aiming to evaluate the complexation between oregano EO and CDs ( $\alpha-\mathrm{CD}$ and $\gamma-\mathrm{CD})$, Figueroa-Lopez et al. [72] compared two methods of IC formation: kneading and spray drying. The kneading method showed greater effectiveness in producing inclusion complexes between the analyzed CDs and the EO. After, the authors incorporated the ICs into poly-based films (3-hydroxybutyrate-co-3-hydroxy valerate) (PHBV) by electrospinning at $160{ }^{\circ} \mathrm{C}$ and observed that the complexation provided not only greater thermal stability to the EO, but also enhanced the antimicrobial and antioxidant properties of the elaborated films and improved their mechanical properties. The films containing ICs lead to a $3 \log$ cycles reduction in the population of Staphylococcus aureus and Escherichia coli.

The ICs containing active molecules can also allow the development of photoactivated antimicrobial films, helping to control possible microbial contamination in foods. Shlar et al. [83] developed polyethylene-terephthalate (PET) films electrostatically loaded with successive layers of poly-L-lysine (-), poly-L-glutamic acid (+), and carboxymethyl- $\beta-$ $\mathrm{CD}$, which was used as the base material for the formation of ICs with curcumin. After successive layers of poly-L-lysine, poly-L-glutamic acid, and CD were deposited on the film, the material was loaded with curcumin by immersion. Due to its photoactive characteristic, curcumin exerts significant antibacterial activity when exposed to white light. This activity was also verified for the elaborated active films. In the dark, the multilayer film presented modest antibacterial activity; however, under light exposure, the antimicrobial activity was enhanced.

Munhuweyi et al. [92], in turn, obtained nanofibers based on chitosan, polyvinyl alcohol (PVA), and $\beta-C D$ to develop active packaging with oregano and cinnamon EOs. The nanofilms were produced by electrospinning and showed potential activity against the mold Botrytis sp. Despite the films containing ICs showed higher antifungal activity than the films containing non complexed EOs, the authors discussed the need for further studies on the controlled release aspect of the active components, aiming higher retention of the biocompounds and their long-term release to optimize the nanofilms performance and ensure food quality.

Also aiming for the obtainment of active antimicrobial films, Hu et al. [88] developed gelatin-based films incorporated with inclusion complexes formed by berberine and HP$\beta-C D$. Berberine chloride hydrate is a quaternary alkaloid, being a natural extract with a recognized broad spectrum of antimicrobial activity. Its complexation with HP- $\beta-C D$ can be considered an alternative to overcome its low solubility in water. The authors verified that the gelatin films containing the ICs exhibited intense activity against $S$. aureus and Candida albicans, in addition to a greater solubility in water, thermal stability, and improvement of mechanical properties.

\subsection{CDs/ICs as Components of Emitting/Adsorbent Sachets or Pads}

CDs and their ICs can also be applied in active packaging as constituents of sachets and pads. Sachets and pads are often the most popular commercialized products available in the market responsible for entrapping antimicrobials and/or act as absorbing agents. Thus, these systems are considered potential tools for the release of active substances in the internal surface of the package, as well for absorb undesirable components (e.g., oxygen, ripening gases, and moisture) $[99,100]$. 
Specifically considering the CDs in emitter systems, the enclosing of inclusion complexes in sachets allows interesting results for food preservation. The absence of direct contact between the food and the active compounds in association with the controlled release through the sachets' material is an approach that allows the diffusion of volatile compounds through the headspace to food components [38,101]. In Japan, for example, antimicrobial sachets containing ICs of $\beta-C D$ and allyl isothiocyanate, the major compound of mustard oil and wasabi, have been accessible to consumers for years and are important allies in bakery products preservation [102].

In the literature, this technique was exploited by Ayala-Zavala and González-Aguilar [101] aiming the preservation of refrigerated fresh-cut tomatoes. The authors prepared sachets containing ICs of garlic EO and $\beta-\mathrm{CD}$, and the developed release system successfully preserved fresh-cut tomatoes for several days under refrigeration. The authors also concluded that the relative humidity in-package can be used as a trigger to release the EOs volatiles from the IC. Therefore, this technology has potential to be applied for fresh products, such as minimally processed foods.

Nonetheless, it is important to emphasize the need for evaluation of active sachets directly into food matrices, since different results can be found when compared with the outcomes obtained during in vitro analysis. Marques et al. [38], for example, evaluated the potential of antimicrobial sachets prepared with Pimenta dioica: $\beta$-CD ICs. The elaborated sachets showed in vitro activity against the pathogen Listeria monocytogenes as well as the food spoilage microorganism Byssochlamys nivea. However, further tests involving the application of the preservative sachets containing the IC in a food system evidenced different outcomes [103]. The authors intentionally inoculated ready-to-eat salads with L. monocytogenes and stored them into packagings containing the antimicrobial sachets. The presence of sachet, however, did not contribute to the salad preservation, conflicting with the results obtained in vitro [38,103]. Furthermore, the sensory analysis with consumers showed that salads stored alongside sachets were the least accepted by the participants. Despite the odor attenuation provided by the complexation with CDs, the sensorial impact of the $\mathrm{EO}$ released from the sachet was determinant to this lower acceptance by the panelists.

The differences evidenced between the in vitro analysis and the study in food systems are important to food preservation research since they demonstrate the need for works that investigate the properties of bioactive compounds not only in vitro, but also when applied in foods. It is worth mentioning that, despite the outcomes obtained by in vitro being valid and indeed important for the research, they do not imply that the same behavior will be verified when testing in food systems. In addition, sensory investigation with consumers is a crucial step when studying the application of complexed volatile compounds in foods [103].

CDs can also be successfully used for the development of active pads. Absorbent pads are already commercially available, especially as a moisture control strategy for fresh products [104]. Taking this into account, some studies have evaluated the incorporation of CDs' inclusion complexes into absorbent pads aiming their application for food preservation. For example, Silva et al. [105] assessed the potential of a new coating for absorbent pads used in chicken packages containing pinosylvin ICs with HP- $\beta-C D$ and HP- $\gamma-C D$. These novel antimicrobial pads were tested against Campylobacter jejuni and common chicken microbiota, both in vitro and in a food system, using chicken fillets and exudates.

The authors tested different concentrations of complexed pinosylvin into pads, and $0.08 \mathrm{mg} \cdot \mathrm{cm}^{-2}$ seemed to be sufficient to exert a bactericidal activity against $C$. jejuni at the incubation temperature of $37^{\circ} \mathrm{C}$. When incubated at $4{ }^{\circ} \mathrm{C}$, pads containing $0.04 \mathrm{mg} \cdot \mathrm{cm}^{-2}$ of IC exhibited activity against the bacteria in both chicken fillets and exudates. Lactic acid bacteria, psychrotrophic, and total viable counts were also significantly reduced by the elaborated antimicrobial pads [105]. During the tests in food system, the authors observed that the ICs elaborated with HP- $\gamma-\mathrm{CDs}$ were more effective than those produced with HP$\beta-C D$, although the in vitro assays led to similar outcomes concerning their antimicrobial action. These results reinforce the need for tests in food systems since discrepancies can be 
observed with the results obtained in vitro. Additionally, it is important to emphasize that the formation of ICs with CDs allowed the increase of pinosylvin solubility in an aqueous medium, which proved to be an advantageous strategy for incorporating hydrophobic bioactive molecules into pads for the preservation of fresh products.

More recently, a similar work developed antibacterial pads based on nonwovens polyethylene terephthalate containing $\beta-C D$ embedded with cinnamaldehyde aiming cold fresh pork preservation [106]. Different from the last-mentioned study that coated the inclusion complexes on the pads, the approach used in this work was to crosslink the $\beta-C D$ embedded with cinnamaldehyde on the surface of the PET matrix. The obtained pads allowed a continuous and uniform release of the bioactive molecule on fat food simulants. The in vitro assays indicated that the antibacterial pads inhibited both Gram-negative (E. coli) and Gram-positive (S. aureus) bacteria. When tested on the food matrix, the results showed that the active pads in combination with tray packaging were able to effectively prolong the shelf life of cold fresh pork through the sustained release of cinnamaldehyde. Along with the long-term antibacterial effect, the elaborated pad also improved both the color and the sensory quality of cold fresh pork [106].

In addition to the development of release systems, CDs can also be an ally for scavenging systems. Some patents have described the potential of non-complexed CDs to be used in porous materials for absorbing substances in food packaging. Woltman et al. [107] developed a thermoplastic porous water-permeable layer material with odor-reducing properties that can be used aiming several applications. The thermoplastic material was treated with a surfactant-modified CD prepared by mixing or chemically reacting a CD-based odor absorbing material with a surfactant-producing compound.

Earlier, Carlucci et al. developed a CD-containing odor control material. In this specific case, the employed CD must present a particle size greater than $12 \mu \mathrm{m}$, which has the advantage over materials manufactured with powdered cyclodextrin by avoiding dust formation problems associated therewith [108]. Therefore, both inventions can be used as a basis for the development of absorbent pads for application in active food packaging systems.

\section{CDs as Polymer Matrices Components}

In addition to the formation of inclusion complexes as a potential tool in developing active packaging, mainly linked to the higher stability conferred to the guest molecule (bioactive component), CDs have also been studied as a component of the polymer matrix itself (Figure 3). The participation of CDs as components of polymer blends may promote a deceleration of both internal and external migration of volatile substances, whether from the packaging material itself or the packaged product, or even the external environment [16]. Thus, the incorporation of "empty" CDs can assist in the removal of a wide variety of substances considered undesirable, such as contaminants and odors, acting as absorption agents [16,90,109].

For example, CDs have been studied targeting cholesterol removal, since, due to their hydrophobic cavity, they have a high affinity with the molecule through non-covalent bonds $[90,109]$. Jia et al., for example, synthesized zein and $\beta$-CD-based films for cholesterol absorption at room temperature. The authors reported that, in addition to the high rate of cholesterol absorption by the elaborated films, they also presented high enzymatic degradation, indicating a bio-based absorption tool for the food industry, as well as a good regeneration capacity since they could be reused at least three times without losing its adsorption effectiveness [90]. 
a.

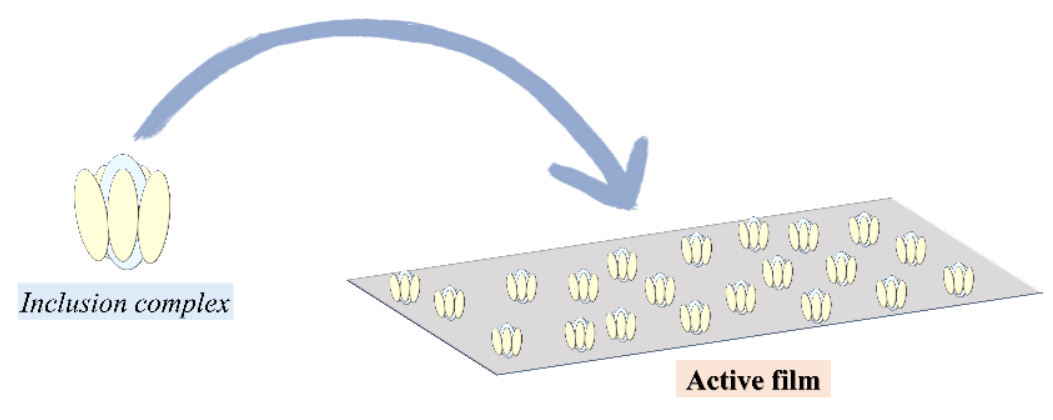

b.

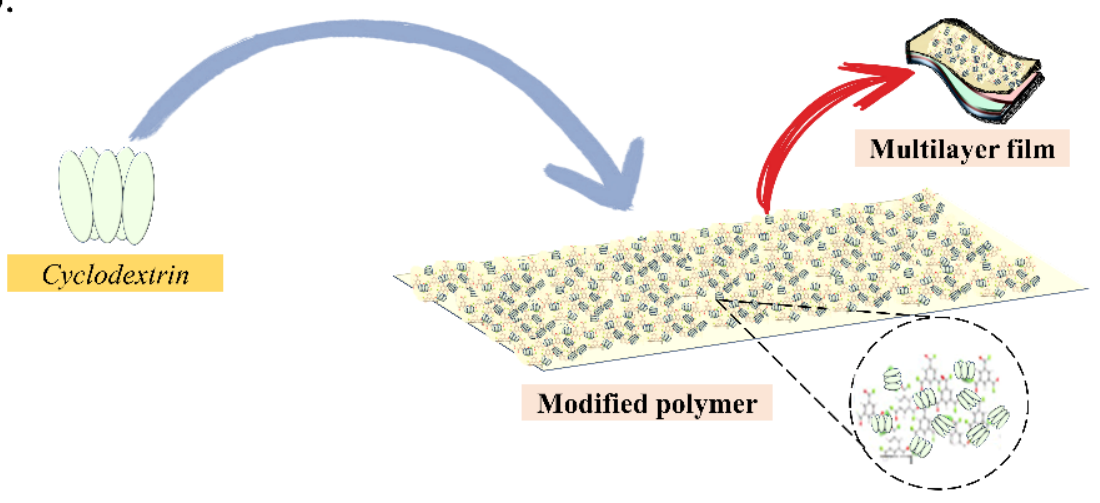

Figure 3. Incorporation of inclusion complex (a) or "empty" CD (b) into polymer matrices.

Chiu et al. [109], in turn, immobilized $\beta$-CD in a chitosan matrix to separate cholesterol in egg yolks, promoting the removal of $92 \%$ of cholesterol from the analyzed samples. The study also emphasized the reuse capacity of the separation matrix, up to 12 times since cholesterol, after complexed with CD, can be released with an ethanolic solution $(95 \% w / w)$ at $50{ }^{\circ} \mathrm{C}$. A process with a similar goal was developed by Dias et al., using $\beta-\mathrm{CD}$ in the removal of cholesterol in butter [110].

When included directly in the polymer matrix, CDs can also act in different ways aside from acting as absorbing agents. Changes in barrier [93] and thermal [91] properties of the packaging, as well as changes in the release profile of active compounds (when the packaging is incorporated with bioactive substances) [92].

The improvement of barrier properties, mainly water vapor barrier, could be useful in particular to polymeric materials with a more hydrophilic nature. Although these materials may show a good barrier against gases, their high water permeability limits their application to certain food products. Even in environments/foods with high moisture content, their sensitivity to water considerably reduces their gas barrier properties [93]. For these materials, the structure of CDs—with their more hydrophilic exterior-allows good chemical compatibility with the polymer matrix. At the same time, its hydrophobic cavity can confer different changes in the functionality of the packaging material. To illustrate this statement, we present, in Figure 4, an example of an inclusion complex of EO and $\beta-\mathrm{CD}$ incorporated into two distinct polymeric materials: cellulose acetate (hydrophobic), and methylcellulose (hydrophilic). It is possible to observe that the IC was better dispersed in the hydrophilic matrix, unlike in the hydrophobic matrix, in which aggregates can be seen. 


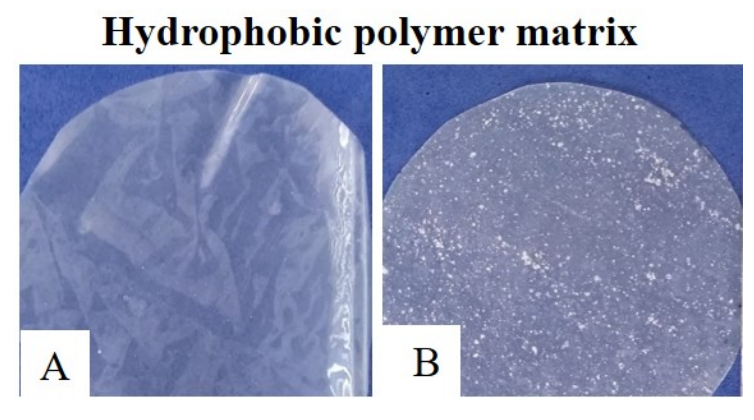

Hydrophilic polymer matrix
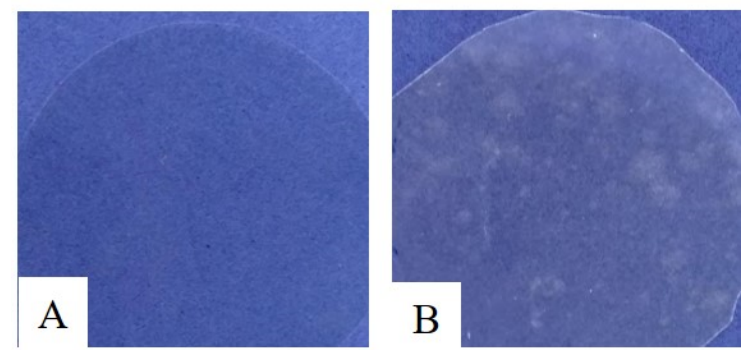

Figure 4. Inclusion complex (IC) of EO and $\beta-\mathrm{CD}$ incorporated into: cellulose acetate matrix (hydrophobic) and methylcellulose matrix (hydrophilic). (A) control film; (B) film incorporated with the IC.

Changes in barrier properties should be studied on a case-by-case basis. As demonstrated by López-de-Dicastillo et al. [93], although the immobilization of $\beta$-CDs was successfully performed in their study, incorporating these molecules into ethylene-vinylalcohol matrix promoted an increase in the polymer vitreous transition temperature and its percentage of crystallinity, promoting a material more brittle. In addition, the presence of $\beta$-CD increased the film permeability to water vapor, oxygen, and carbon dioxide. Similarly, Dias et al. [40] and Marques et al. [12] noticed that the incorporation of inclusion complexes of allyl isothiocyanate and $\beta-\mathrm{CD}$ into cellulose acetate leads to films more frails and with more irregular topography, probably due to nonsolubility of $\beta-\mathrm{CD}$ in acetone, the solvent used for the films' preparation.

On the other hand, when it comes to polymeric materials with a more hydrophobic nature, such as poly(lactic acid) (PLA), higher hydrophilicity can be achieved by incorporating CDs directly into the polymer matrix through the development of multilayer packaging. This characteristic can increase biological properties, for example, biodegradability. In addition, improvement in the profile of bioactive substances of hydrophobic nature can be achieved changing the hydrophobicity of the polymeric matrix in which they were incorporated [91].

\section{Toxicological and Regulatory Aspects: Food and Food Packaging}

As already mentioned, CDs are considered safe for use in food, and regulatory status suggests that a possible migration of CDs from packaging to the packaged food does not induce the appearance of harmful effects on consumers [16]. While granted GRAS status by the FDA in Europe, although there is no limit regarding the intake of $\alpha$ - and $\gamma-\mathrm{CD}$, when it comes to $\beta-C D$, there is a pre-established maximum acceptable daily intake of $0.5 \mathrm{mg} \cdot \mathrm{kg}^{-1}$ of body weight [111]. $\alpha-, \beta$ - and $\gamma$-CDs are registered in the Codex Alimentarius of the FAO/WHO Joint Committee of Food Additive specialists with the International Numbering System (INS) No. 457, 459, and 458, respectively, among the General Standard Food Additives (GFSA) (GSFA, 2019). In turn, $\beta$-CD is registered in the EU as an additive E-459 (Official Journal of the European Union L283/77) [112], which underwent revision in 2016 but did not culminate in changes [111].

As for derived molecules, some chemically modified CDs, such as hydroxypropyl- $\alpha-$, $\beta$ - and $\gamma$-CDs (HP- $\alpha$-CD, HP- $\beta$-CD, HP $\gamma$-CD) and random $\alpha-, \beta$ - and $\gamma$-CDs (RAME- $\alpha$, 
RAME- $\beta$, RAME- $\gamma$ ) are approved as drug excipients, however, have not yet been recognized as ingredients for use in food [113]. Considering the regulatory aspects concerning the use of CDs in food packaging, regulatory status suggests that the eventual migration of these molecules to packaged foods has no harmful effects on consumers [16].

\section{Conclusions}

The different types of CDs available in the market or synthesized in laboratories are promising additives for application in food packaging elaboration to improve the quality, safety, and shelf life of foods. Versatile, they can be used as inclusion complexes, entrapping compounds of interest, as well as "empty", and be employed in emitter systems, releasing substances into the packaged food, or in absorbent materials, removing undesirable components. Among the native CDs, $\beta-C D$ is the more studied and applied due to its low price and cavity size. The incorporation of CDs into polymer matrices is also possible, and there are several methods described in the literature aiming their addition in the base polymer allowing the attainment of materials with different properties. Hydrophobic and hydrophilic polymers can be used as matrices for incorporation of active ICs or even CDs themselves, enabling the production of packages with different characteristics, including multilayer films.

The ability of CDs to accommodate certain molecules, ensure their protection from external factors, and promote their controlled release is an important advantage to the food industry. Therefore, complexation with CDs extends the range of compounds that can be used in active packaging production, such as antimicrobial volatiles, which are not usually considered as packaging additives due to their proneness to volatilization and degradation. Since the manufacture of packaging usually involves high temperatures, the stabilization of volatile compounds with CDs and the protection granted by them is essential for their incorporation in this context. Based on the above considerations, CDs and their ICs comprise an interesting prospect that is increasingly being explored as a potential tool for food packaging development.

Author Contributions: Conceptualization, writing-original draft preparation: T.R.A.; Conceptualization, writing - review and editing: C.S.M.; supervision, funding acquisition, and project administration: N.F.F.S. All authors have read and agreed to the published version of the manuscript.

Funding: This research was funded by National Council for Scientific and Technological Development (grant number 142564/2018-4). In addition, this study was financed in part by the Coordenação de Aperfeiçoamento de Pessoal de Nível Superior-Brasil (CAPES)-Finance code 001 and grant number 88887.497825/2020-00.

Institutional Review Board Statement: Not applicable.

Informed Consent Statement: Not applicable.

Acknowledgments: The authors would like to thank the Federal University of Viçosa and the Food Packaging Laboratory-LABEM/UFV for support, knowledge, and infrastructure.

Conflicts of Interest: The authors declare no conflict of interest.

\section{References}

1. Morin-Crini, N.; Fourmentin, S.; Fenyvesi, E.; Lichtfouse, E.; Torri, G.; Fourmentin, M.; Crini, G. 130 years of cyclodextrin discovery for health, food, agriculture, and the industry: A review. Environ. Chem. Lett. 2021, 19, 2581-2617. [CrossRef]

2. Jansook, P.; Ogawa, N.; Loftsson, T. Cyclodextrins: Structure, physicochemical properties and pharmaceutical applications. Int. J. Pharm. 2018, 535, 272-284. [CrossRef] [PubMed]

3. He, Y.; Zeng, S.; El-Aty, A.M.A.; Hacımüftüoğlu, A.; Yohannes, W.K.; Khan, M.; She, Y. Development of Water-Compatible Molecularly Imprinted Polymers Based on Functionalized $\beta$-Cyclodextrin for Controlled Release of Atropine. Polymers 2020, 12, 130. [CrossRef]

4. Mai, N.N.S.; Nakai, R.; Kawano, Y.; Hanawa, T. Enhancing the Solubility of Curcumin Using a Solid Dispersion System with Hydroxypropyl- $\beta$-Cyclodextrin Prepared by Grinding, Freeze-Drying, and Common Solvent Evaporation Methods. Pharmacy 2020, 8, 203. [CrossRef] 
5. Torchio, A.; Cassino, C.; Lavella, M.; Gallina, A.; Stefani, A.; Boffito, M.; Ciardelli, G. Injectable supramolecular hydrogels based on custom-made poly(ether urethane)s and $\alpha$-cyclodextrins as efficient delivery vehicles of curcumin. Mater. Sci. Eng. C 2021, 127, 112194. [CrossRef]

6. Hashimoto, H. Present Status of Industrial Application of Cyclodextrins in Japan. J. Incl. Phenom. Macrocycl. Chem. 2002, 44, 57-62. [CrossRef]

7. Novozymes Home Page. Available online: https://www.novozymes.com/en (accessed on 10 September 2021).

8. Wacker Chemie AG Home Page. Available online: https://www.wacker.com/cms/en-us/home/home.html (accessed on 10 September 2021).

9. Roquette Frères Home Page. Available online: https://www.roquette.com (accessed on 10 September 2021).

10. Cyclo Therapeutics, Inc. Home Page. Available online: https://www.cyclodex.com (accessed on 10 September 2021).

11. Yeguas, V.; Altarsha, M.; Monard, G.; López, R.; Ruiz-López, M.F. Peptide Binding to $\beta$-Cyclodextrins: Structure, Dynamics, Energetics, and Electronic Effects. J. Phys. Chem. A 2011, 115, 11810-11817. [CrossRef] [PubMed]

12. Marques, C.S.; Dias, M.V.; Soares, N.D.F.F.; Borges, S.V.; de Oliveira, I.R.N.; Pires, A.C.D.S.; Medeiros, E.A.A.; Alves, E. Ultrastructural and antimicrobial impacts of allyl isothiocyanate incorporated in cellulose, $\beta$-cyclodextrin, and carbon nanotubes nanocomposites. J. Vinyl Addit. Technol. 2021. [CrossRef]

13. Dermawan, D.; Wathoni, N.; Muchtaridi, M. Host-Guest Interactions of $\alpha$-Mangostin with $(\alpha, \beta, \gamma)-$ Cyclodextrins: SemiEmpirical Quantum Mechanical Methods of PM6 and PM7. J. Young Pharm. 2018, 11, 31-35. [CrossRef]

14. Piletti, R.; Zanetti, M.; Jung, G.; de Mello, J.M.M.; Dalcanton, F.; Soares, C.; Riella, H.; Fiori, M.A. Microencapsulation of garlic oil by $\beta$-cyclodextrin as a thermal protection method for antibacterial action. Mater. Sci. Eng. C 2018, 94, 139-149. [CrossRef]

15. Kumar, S.; Trotta, F.; Rao, R. Encapsulation of Babchi Oil in Cyclodextrin-Based Nanosponges: Physicochemical Characterization, Photodegradation, and In Vitro Cytotoxicity Studies. Pharmaceutics 2018, 10, 169. [CrossRef] [PubMed]

16. Szente, L.; Fenyvesi, É. Cyclodextrin-Enabled Polymer Composites for Packaging. Molecules 2018, 23, 1556. [CrossRef] [PubMed]

17. Loftsson, T.; Brewster, M.E. Cyclodextrins as Functional Excipients: Methods to Enhance Complexation Efficiency. J. Pharm. Sci. 2012, 101, 3019-3032. [CrossRef] [PubMed]

18. Sonnendecker, C.; Melzer, S.; Zimmermann, W. Engineered cyclodextrin glucanotransferases from Bacillus sp. G-825-6 produce large-ring cyclodextrins with high specificity. MicrobiologyOpen 2018, 8, e00757. [CrossRef] [PubMed]

19. Marques, H.M.C. A review on cyclodextrin encapsulation of essential oils and volatiles. Flavour Fragr. J. 2010, 25, 313-326. [CrossRef]

20. Kfoury, M.; Auezova, L.; Ruellan, S.; Greige-Gerges, H.; Fourmentin, S. Complexation of estragole as pure compound and as main component of basil and tarragon essential oils with cyclodextrins. Carbohydr. Polym. 2015, 118, 156-164. [CrossRef]

21. De Miranda, J.C.; Martins, T.E.A.; Veiga, F.; Ferraz, H.G. Cyclodextrins and ternary complexes: Technology to improve solubility of poorly soluble drugs. Braz. J. Pharm. Sci. 2011, 47, 665-681. [CrossRef]

22. Stańczak, A.; Kołodziejczyk, M. Characteristic of Cyclodextrins: Their Role and Use in the Pharmaceutical Technology. Curr. Drug Targets 2020, 21, 1495-1510. [CrossRef]

23. Buckley, J.D.; Coates, A.M.; Ranald, P.; Howe, C. Fiber Ingredients: Food Applications and Health Benefits, 1st ed.; Cho, S.S., Samuel, P., Eds.; CRC Press: Boca Raton, FL, USA, 2009; pp. 9-18, ISBN 9780429144776.

24. U.S. Food and Drug Administration Home Page. Available online: http:/ / www.fda.gov/ (accessed on 10 September 2021).

25. Väkeväinen, K.; Rinkinen, N.; Willman, R.-M.; Lappi, J.; Raninen, K.; Kårlund, A.; Mikkonen, S.; Plumed-Ferrer, C.; Kolehmainen, M. Potential of Probiotic Frozen Blackcurrant Products: Consumer Preference, Physicochemical Characterization, and Cell Viability. Foods 2021, 10, 792. [CrossRef]

26. Henck, J.M.; Bis-Souza, C.V.; Pollonio, M.A.; Lorenzo, J.M.; Barretto, A.C.D.S. Alpha-cyclodextrin as a new functional ingredient in low-fat chicken frankfurter. Br. Poult. Sci. 2019, 60, 716-723. [CrossRef]

27. Bazzano, M.; Barolo, C.; Buscaino, R.; D’Agostino, G.; Ferri, A.; Sangermano, M.; Pisano, R. Controlled Atmosphere in Food Packaging Using Ethylene- $\alpha$-Cyclodextrin Inclusion Complexes Dispersed in Photocured Acrylic Films. Ind. Eng. Chem. Res. 2016, 55, 579-585. [CrossRef]

28. Ariyanto, H.D.; Chiba, M.; Oguma, K.; Tatsuki, M.; Yoshii, H. Release behavior of 1-methylcylopropene coated paper-based shellac solution in response to stepwise humidity changes to develop novel functional packaging for fruit. Packag. Technol. Sci. 2019, 32, 523-533. [CrossRef]

29. Kayaci, F.; Uyar, T. Encapsulation of vanillin/cyclodextrin inclusion complex in electrospun polyvinyl alcohol (PVA) nanowebs: Prolonged shelf-life and high temperature stability of vanillin. Food Chem. 2012, 133, 641-649. [CrossRef]

30. Kayaci, F.; Ertas, Y.; Uyar, T. Enhanced Thermal Stability of Eugenol by Cyclodextrin Inclusion Complex Encapsulated in Electrospun Polymeric Nanofibers. J. Agric. Food Chem. 2013, 61, 8156-8165. [CrossRef]

31. Samperio, C.; Boyer, R.; Eigel, W.N.; Holland, K.W.; McKinney, J.S.; O’Keefe, S.F.; Smith, R.; Marcy, J.E. Enhancement of Plant Essential Oils' Aqueous Solubility and Stability Using Alpha and Beta Cyclodextrin. J. Agric. Food Chem. 2010, 58, 12950-12956. [CrossRef]

32. Câmara, A.K.F.I.; Paglarini, C.S.; Vidal, V.A.S.; Santos, M.; Pollonio, M.A.R. Advances in Food and Nutrition Research, 1st ed.; da Cruz, A.G., Prudencio, E.S., Esmerino, E.A., da Silva, M.C., Eds.; Academic Press: Cambridge, MA, USA, 2020; Volume 94, pp. 223-265, ISBN 9780128202180. 
33. Pan, J.; Ai, F.; Shao, P.; Chen, H.; Gao, H. Development of polyvinyl alcohol/ $\beta$-cyclodextrin antimicrobial nanofibers for fresh mushroom packaging. Food Chem. 2019, 300, 125249. [CrossRef] [PubMed]

34. Cui, H.; Wang, Y.; Li, C.; Chen, X.; Lin, L. Antibacterial efficacy of Satureja montana L. essential oil encapsulated in methyl- $\beta$ cyclodextrin/soy soluble polysaccharide hydrogel and its assessment as meat preservative. LWT 2021, 152, 112427. [CrossRef]

35. Zou, Y.; Yuan, C.; Cui, B.; Wang, J.; Yu, B.; Guo, L.; Dong, D. Mechanical and antimicrobial properties of high amylose corn starch/konjac glucomannan composite film enhanced by cinnamaldehyde/ $\beta$-cyclodextrin complex. Ind. Crop. Prod. 2021, 170, 113781. [CrossRef]

36. Zou, Y.; Yuan, C.; Cui, B.; Sha, H.; Liu, P.; Lu, L.; Wu, Z. High-Amylose Corn Starch/Konjac Glucomannan Composite Film: Reinforced by Incorporating $\beta$-Cyclodextrin. J. Agric. Food Chem. 2021, 69, 2493-2500. [CrossRef]

37. Chen, Z.; Zong, L.; Chen, C.; Xie, J. Development and characterization of PVA-Starch active films incorporated with $\beta$-cyclodextrin inclusion complex embedding lemongrass (Cymbopogon citratus) oil. Food Packag. Shelf Life 2020, 26, 100565. [CrossRef]

38. Marques, C.S.; Carvalho, S.G.; Bertoli, L.D.; Villanova, J.C.O.; Pinheiro, P.F.; dos Santos, D.C.M.; Yoshida, M.I.; de Freitas, J.C.C.; Cipriano, D.F.; Bernardes, P. $\beta$-Cyclodextrin inclusion complexes with essential oils: Obtention, characterization, antimicrobial activity and potential application for food preservative sachets. Food Res. Int. 2019, 119, 499-509. [CrossRef] [PubMed]

39. Chen, H.; Li, L.; Ma, Y.; Mcdonald, T.P.; Wang, Y. Development of active packaging film containing bioactive components encapsulated in $\beta$-cyclodextrin and its application. Food Hydrocoll. 2018, 90, 360-366. [CrossRef]

40. Dias, M.V.; Sousa, M.M.; Lara, B.R.B.; de Azevedo, V.M.; Soares, N.D.F.F.; Borges, S.V.; Queiroz, F. Thermal and morphological properties and kinetics of diffusion of antimicrobial films on food and a simulant. Food Packag. Shelf Life 2018, 16, 15-22. [CrossRef]

41. Voncina, B.; Vivod, V.; Chen, W.-T. Surface modification of PET fibers with the use of $\beta$-cyclodextrin. J. Appl. Polym. Sci. 2009, 113, 3891-3895. [CrossRef]

42. Szente, L. Highly soluble cyclodextrin derivatives: Chemistry, properties, and trends in development. Adv. Drug Deliv. Rev. 1999, 36, 17-28. [CrossRef]

43. Freudenberg, K.; Jacobi, R. Über Schardingers Dextrine aus Stärke. Eur. J. Org. Chem. 1935, 518, 102-108. [CrossRef]

44. Saokham, P.; Loftsson, T. $\gamma$-Cyclodextrin. Int. J. Pharm. 2017, 516, 278-292. [CrossRef] [PubMed]

45. Praphanwittaya, P.; Saokham, P.; Jansook, P.; Loftsson, T. Aqueous solubility of kinase inhibitors: I the effect of hydrophilic polymers on their $\gamma$-cyclodextrin solubilization. J. Drug Deliv. Sci. Technol. 2019, 55, 101462. [CrossRef]

46. Jansook, P.; Pichayakorn, W.; Muankaew, C.; Loftsson, T. Cyclodextrin-poloxamer aggregates as nanocarriers in eye drop formulations: Dexamethasone and amphotericin B. Drug Dev. Ind. Pharm. 2016, 42, 1446-1454. [CrossRef]

47. Bastianini, M.; Sisani, M.; Petracci, A. Ascorbyl Tetraisopalmitate Inclusion into $\Upsilon$-Cyclodextrin and Mesoporous SBA-15: Preparation, Characterization and In Vitro Release Study. Cosmetics 2017, 4, 21. [CrossRef]

48. Chen, L.; Zhu, D.-D.; Ji, G.-J.; Yuan, S.; Qian, J.-F.; He, M.-Y.; Chen, Q.; Zhang, Z.-H. Efficient adsorption separation of xylene isomers using a facilely fabricated cyclodextrin-based metal-organic framework. J. Chem. Technol. Biotechnol. 2018, 93, $2898-2905$. [CrossRef]

49. Savarino, P.; Viscardi, G.; Quagliotto, P.; Montoneri, E.; Barni, E. Reactivity and effects of cyclodextrins in textile dyeing. Dye. Pigment. 1999, 42, 143-147. [CrossRef]

50. Huang, K.; Zhang, D.; Ren, J.-J.; Dong, R.; Wu, H. Screening of the Repellent Activity of 12 Essential Oils Against Adult German Cockroach (Dictyoptera: Blattellidae): Preparation of a Sustained Release Repellent Agent of Binary Oil- $\gamma$-CD and its Repellency in a Small Container. J. Econ. Èntomol. 2020, 113, 2171-2178. [CrossRef] [PubMed]

51. Feng, T.; Zhuang, H.; Ran, Y. The Application of Cyclodextrin Glycosyltransferase in Biological Science. J. Bioequivalence Bioavailab. 2011, 3, 202-206. [CrossRef]

52. Assaf, K.I.; Gabel, D.; Zimmermann, W.; Nau, W.M. High-affinity host-guest chemistry of large-ring cyclodextrins. Org. Biomol. Chem. 2016, 14, 7702-7706. [CrossRef]

53. Yan, T.; Ji, M.; Sun, Y.; Zhao, J.; Zhang, H.; Wang, Z. Preparation and characterization of baicalein/hydroxypropyl- $\beta$-cyclodextrin inclusion complex for enhancement of solubility, antioxidant activity and antibacterial activity using supercritical antisolvent technology. J. Incl. Phenom. Macrocycl. Chem. 2019, 96, 285-295. [CrossRef]

54. Garrido, P.F.; Calvelo, M.; Blanco-González, A.; Veleiro, U.; Suárez, F.; Conde, D.; Cabezón, A.; Piñeiro, Á.; Garcia-Fandino, R. The Lord of the NanoRings: Cyclodextrins and the battle against SARS-CoV-2. Int. J. Pharm. 2020, 588, 119689. [CrossRef]

55. Mavridis, I.M.; Yannakopoulou, K. Anionic cyclodextrins as versatile hosts for pharmaceutical nanotechnology: Synthesis, drug delivery, enantioselectivity, contrast agents for MRI. Int. J. Pharm. 2015, 492, 275-290. [CrossRef] [PubMed]

56. Raza, A.; Sun, H.; Bano, S.; Zhao, Y.; Xu, X.; Tang, J. Preparation, characterization, and in vitro anti-inflammatory evaluation of novel water soluble kamebakaurin/hydroxypropyl- $\beta$-cyclodextrin inclusion complex. J. Mol. Struct. 2017, 1130, 319-326. [CrossRef]

57. Lakka, A.; Lalas, S.; Makris, D.P. Hydroxypropyl- $\beta$-Cyclodextrin as a Green Co-Solvent in the Aqueous Extraction of Polyphenols from Waste Orange Peels. Beverages 2020, 6, 50. [CrossRef]

58. Wu, J.; Sun, X.; Guo, X.; Ji, M.; Wang, J.; Cheng, C.; Chen, L.; Wen, C.; Zhang, Q. Physicochemical, Antioxidant, In Vitro Release, and Heat Sealing Properties of Fish Gelatin Films Incorporated with $\beta$-Cyclodextrin/Curcumin Complexes for Apple Juice Preservation. Food Bioprocess Technol. 2017, 11, 447-461. [CrossRef]

59. Zhang, L.; Huang, C.; Xu, Y.; Huang, H.; Zhao, H.; Wang, J.; Wang, S. Synthesis and characterization of antibacterial polylactic acid film incorporated with cinnamaldehyde inclusions for fruit packaging. Int. J. Biol. Macromol. 2020, 164, 4547-4555. [CrossRef] 
60. Celebioglu, A.; Uyar, T. Development of ferulic acid/cyclodextrin inclusion complex nanofibers for fast-dissolving drug delivery system. Int. J. Pharm. 2020, 584, 119395. [CrossRef] [PubMed]

61. Wei, Y.; Zhang, J.; Zhou, Y.; Bei, W.; Li, Y.; Yuan, Q.; Liang, H. Characterization of glabridin/hydroxypropyl- $\beta$-cyclodextrin inclusion complex with robust solubility and enhanced bioactivity. Carbohydr. Polym. 2017, 159, 152-160. [CrossRef]

62. Giacoppo, S.; Rajan, T.S.; Iori, R.; Rollin, P.; Bramanti, P.; Mazzon, E. The $\alpha$-cyclodextrin complex of the Moringa isothiocyanate suppresses lipopolysaccharide-induced inflammation in RAW 264.7 macrophage cells through Akt and p38 inhibition. Inflamm. Res. 2017, 66, 487-503. [CrossRef]

63. Yildiz, Z.I.; Kilic, M.E.; Durgun, E.; Uyar, T. Molecular Encapsulation of Cinnamaldehyde within Cyclodextrin Inclusion Complex Electrospun Nanofibers: Fast-Dissolution, Enhanced Water Solubility, High Temperature Stability, and Antibacterial Activity of Cinnamaldehyde. J. Agric. Food Chem. 2019, 67, 11066-11076. [CrossRef]

64. Celebioglu, A.; Uyar, T. Fast-dissolving antioxidant curcumin/cyclodextrin inclusion complex electrospun nanofibrous webs. Food Chem. 2020, 317, 126397. [CrossRef] [PubMed]

65. Celebioglu, A.; Yildiz, Z.I.; Uyar, T. Fabrication of Electrospun Eugenol/Cyclodextrin Inclusion Complex Nanofibrous Webs for Enhanced Antioxidant Property, Water Solubility, and High Temperature Stability. J. Agric. Food Chem. 2018, 66, 457-466. [CrossRef]

66. Fateminasab, F.; Bordbar, A.; Shityakov, S.; Saboury, A. Molecular insights into inclusion complex formation between $\beta$ - and $\gamma$-cyclodextrins and rosmarinic acid. J. Mol. Liq. 2020, 314, 113802. [CrossRef]

67. Aytac, Z.; Ipek, S.; Durgun, E.; Uyar, T. Antioxidant electrospun zein nanofibrous web encapsulating quercetin/cyclodextrin inclusion complex. J. Mater. Sci. 2017, 53, 1527-1539. [CrossRef]

68. Nguyen, T.V.A.; Yoshii, H. Release behavior of allyl sulfide from cyclodextrin inclusion complex of allyl sulfide under different storage conditions. Biosci. Biotechnol. Biochem. 2018, 82, 848-855. [CrossRef]

69. Aytac, Z.; Yildiz, Z.I.; Kayaci-Senirmak, F.; Tekinay, T.; Uyar, T. Electrospinning of cyclodextrin/linalool-inclusion complex nanofibers: Fast-dissolving nanofibrous web with prolonged release and antibacterial activity. Food Chem. 2017, 231, 192-201. [CrossRef] [PubMed]

70. Santos, E.H.; Kamimura, J.A.; Hill, L.E.; Gomes, C.L. Characterization of carvacrol beta-cyclodextrin inclusion complexes as delivery systems for antibacterial and antioxidant applications. LWT 2015, 60, 583-592. [CrossRef]

71. Sapkal, N.P.; Kilor, V.; Bhursari, K.P.; Daud, A.S. Evaluation of some Methods for Preparing Gliclazide- $\beta$-Cyclodextrin Inclusion Complexes. Trop. J. Pharm. Res. 2007, 6, 833-840. [CrossRef]

72. Figueroa-Lopez, K.J.; Enescu, D.; Torres-Giner, S.; Cabedo, L.; Cerqueira, M.A.; Pastrana, L.; Fuciños, P.; Lagaron, J.M. Development of electrospun active films of poly(3-hydroxybutyrate-co-3-hydroxyvalerate) by the incorporation of cyclodextrin inclusion complexes containing oregano essential oil. Food Hydrocolloids 2020, 108, 106013. [CrossRef]

73. Zhang, Q.-F.; Jiang, Z.-T.; Li, R. Complexation of allyl isothiocyanate with $\beta$-cyclodextrin and its derivatives and molecular microcapsule of allyl isothiocyanate in $\beta$-cyclodextrin. Eur. Food Res. Technol. 2006, 225, 407-413. [CrossRef]

74. Han, P.; Zhong, Y.; An, N.; Lu, S.; Wang, Q.; Dong, J. Preparation, characterization, and molecular modeling of sesamol/ $\beta$ cyclodextrin derivatives inclusion complexes. J. Mol. Liq. 2021, 339, 116790. [CrossRef]

75. Franco, P.; de Marco, I. Formation of Rutin- $\beta$-Cyclodextrin Inclusion Complexes by Supercritical Antisolvent Precipitation. Polymers 2021, 13, 246. [CrossRef]

76. Meo, P.L.; D'Anna, F.; Riela, S.; Gruttadauria, M.; Noto, R. Spectrophotometric study on the thermodynamics of binding of $\alpha$ - and $\beta$-cyclodextrin towards some p-nitrobenzene derivatives. Org. Biomol. Chem. 2003, 1, 1584-1590. [CrossRef]

77. Hădărugă, N.G.; Bandur, G.N.; Hădărugă, D.I. Cyclodextrin Fundamentals, Reactivity and Analysis, 1st ed.; Fourmentin, S., Crini, G., Lichtfouse, E., Eds.; Springer: Cham, Switzerland, 2018; pp. 155-221, ISBN 9783319761596.

78. Biedermann, F.; Nau, W.; Schneider, H.-J. The Hydrophobic Effect Revisited-Studies with Supramolecular Complexes Imply High-Energy Water as a Noncovalent Driving Force. Angew. Chem. Int. Ed. 2014, 53, 11158-11171. [CrossRef] [PubMed]

79. Cheriet, M.; Djemil, R.; Khellaf, A.; Khatmi, D. Dopamine Family Complexes with $\beta$-Cyclodextrin: Molecular Docking Studies. Polycycl. Aromat. Compd. 2021, 1-10. [CrossRef]

80. Charumanee, S.; Titwan, A.; Sirithunyalug, J.; Weiss-Greiler, P.; Wolschann, P.; Viernstein, H.; Okonogi, S. Thermodynamics of the encapsulation by cyclodextrins. J. Chem. Technol. Biotechnol. 2006, 81, 523-529. [CrossRef]

81. Tao, F.; Hill, L.E.; Peng, Y.; Gomes, C.L. Synthesis and characterization of $\beta$-cyclodextrin inclusion complexes of thymol and thyme oil for antimicrobial delivery applications. LWT 2014, 59, 247-255. [CrossRef]

82. Shin, J.; Kathuria, A.; Lee, Y.S. Effect of hydrophilic and hydrophobic cyclodextrins on the release of encapsulated allyl isothiocyanate (AITC) and their potential application for plastic film extrusion. J. Appl. Polym. Sci. 2019, 136. [CrossRef]

83. Shlar, I.; Droby, S.; Rodov, V. Antimicrobial coatings on polyethylene terephthalate based on curcumin/cyclodextrin complex embedded in a multilayer polyelectrolyte architecture. Colloids Surfaces B Biointerfaces 2018, 164, 379-387. [CrossRef]

84. Aytac, Z.; Kusku, S.I.; Durgun, E.; Uyar, T. Encapsulation of gallic acid/cyclodextrin inclusion complex in electrospun polylactic acid nanofibers: Release behavior and antioxidant activity of gallic acid. Mater. Sci. Eng. C 2016, 63, 231-239. [CrossRef] [PubMed]

85. Byun, Y.; Rodriguez, K.; Han, J.H.; Kim, Y.T. Improved thermal stability of polylactic acid (PLA) composite film via PLA- $\beta$ cyclodextrin-inclusion complex systems. Int. J. Biol. Macromol. 2015, 81, 591-598. [CrossRef] 
86. Wen, P.; Zhu, D.-H.; Feng, K.; Liu, F.-J.; Lou, W.-Y.; Li, N.; Zong, M.-H.; Wu, H. Fabrication of electrospun polylactic acid nanofilm incorporating cinnamon essential oil/ $\beta$-cyclodextrin inclusion complex for antimicrobial packaging. Food Chem. 2015, 196, 996-1004. [CrossRef]

87. Barba, C.; Eguinoa, A.; Maté, J.I. Preparation and characterization of $\beta$-cyclodextrin inclusion complexes as a tool of a controlled antimicrobial release in whey protein edible films. LWT 2015, 64, 1362-1369. [CrossRef]

88. Hu, X.; Yuan, L.; Han, L.; Li, S.; Zhou, W. The preparation, characterization, anti-ultraviolet and antimicrobial activity of gelatin film incorporated with berberine-HP- $\beta$-CD. Colloids Surfaces A Physicochem. Eng. Asp. 2019, 586, 124273. [CrossRef]

89. Mallardo, S.; De Vito, V.; Malinconico, M.; Volpe, M.G.; Santagata, G.; Di Lorenzo, M.L. Poly(butylene succinate)-based composites containing $\beta$-cyclodextrin/d-limonene inclusion complex. Eur. Polym. J. 2016, 79, 82-96. [CrossRef]

90. Jia, X.; Yang, N.; Qi, X.; Chen, L.; Zhao, Y. Adsorptive removal of cholesterol by biodegradable zein-graft- $\beta$-cyclodextrin film. Int. J. Biol. Macromol. 2020, 155, 293-304. [CrossRef]

91. Olmo, J.A.-D.; Álvarez, L.P.; Hernáez, E.; Ruiz-Rubio, L.; Vilas-Vilela, J.L. Antibacterial multilayer of chitosan and (2-carboxyethyl)$\beta$-cyclodextrin onto polylactic acid (PLLA). Food Hydrocoll. 2018, 88, 228-236. [CrossRef]

92. Munhuweyi, K.; Caleb, O.J.; van Reenen, A.J.; Opara, U.L. Physical and antifungal properties of $\beta$-cyclodextrin microcapsules and nanofibre films containing cinnamon and oregano essential oils. LWT 2018, 87, 413-422. [CrossRef]

93. López-De-Dicastillo, C.; Gallur, M.; Catalá, R.; Gavara, R.; Hernández-Muñoz, P. Immobilization of $\beta$-cyclodextrin in ethylenevinyl alcohol copolymer for active food packaging applications. J. Membr. Sci. 2010, 353, 184-191. [CrossRef]

94. Lizundia, E.; Gómez-Galván, F.; Pérez-Álvarez, L.; León, L.; Vilas, J. Poly(L-lactide)/branched $\beta$-cyclodextrin blends: Thermal, morphological and mechanical properties. Carbohydr. Polym. 2016, 144, 25-32. [CrossRef]

95. Robertson, G.L. Food Packaging: Principles and Practice, 3rd ed.; CRC Press: Boca Raton, FL, USA, 2013; p. 733, ISBN 9781439862414.

96. Wrona, M.; Silva, F.; Salafranca, J.; Nerín, C.; Alfonso, M.J.; Caballero, M. Design of new natural antioxidant active packaging: Screening flowsheet from pure essential oils and vegetable oils to ex vivo testing in meat samples. Food Control. 2020, 120, 107536. [CrossRef]

97. European Comission. Commission Regulation (EC) N ${ }^{\circ} .450 / 2009$ on Active and Intelligent Materials and Articles Intended to Come into Contact with Food. 2009. Available online: https:/ / eur-lex.europa.eu/LexUriServ/LexUriServ.do?uri=OJ:L:2009:135: 0003:0011:EN:PDF (accessed on 16 September 2021).

98. Mangaraj, S.; Yadav, A.; Bal, L.M.; Dash, S.K.; Mahanti, N.K. Application of Biodegradable Polymers in Food Packaging Industry: A Comprehensive Review. J. Packag. Technol. Res. 2018, 3, 77-96. [CrossRef]

99. Yildirim, S.; Röcker, B.; Pettersen, M.K.; Nilsen-Nygaard, J.; Ayhan, Z.; Rutkaite, R.; Radusin, T.; Suminska, P.; Marcos, B.; Coma, V. Active Packaging Applications for Food. Compr. Rev. Food Sci. Food Saf. 2017, 17, 165-199. [CrossRef]

100. Restuccia, D.; Salomone, R.; Spizzirri, U.G.; Saija, G.; Ioppolo, G.; Parisi, O.I.; Picci, N. Industrial applications: Regulatory issues and life cycle assessment of food packaging, 1st ed.; Academic Press: London, UK, 2016; pp. 215-227, ISBN 9780128007235.

101. Ayala-Zavala, J.F.; González-Aguilar, G.A. Optimizing the Use of Garlic Oil as Antimicrobial Agent on Fresh-Cut Tomato through a Controlled Release System. J. Food Sci. 2010, 75, M398-M405. [CrossRef] [PubMed]

102. Mitsubishi Chemical Corporation Home Page. Available online: https://www.mfc.co.jp/wasaouro/eng/about/index.html (accessed on 22 September 2021).

103. Marques, C.S.; Grillo, R.P.; Bravim, D.G.; Pereira, P.V.; Villanova, J.C.O.; Pinheiro, P.F.; Carneiro, J.C.S.; Bernardes, P.C. Preservation of ready-to-eat salad: A study with combination of sanitizers, ultrasound, and essential oil-containing $\beta$-cyclodextrin inclusion complex. LWT 2019, 115, 108433. [CrossRef]

104. Novipax Home Page. Available online: http://www.novipax.com/markets/fresh-produce/ (accessed on 22 September 2021).

105. Silva, F.; Domingues, F.C.; Nerín, C. Control microbial growth on fresh chicken meat using pinosylvin inclusion complexes based packaging absorbent pads. LWT 2018, 89, 148-154. [CrossRef]

106. Zhou, Z.; Liu, Y.; Liu, Z.; Fan, L.; Dong, T.; Jin, Y.; Saldaña, M.D.; Sun, W. Sustained-release antibacterial pads based on nonwovens polyethylene terephthalate modified by $\beta$-cyclodextrin embedded with cinnamaldehyde for cold fresh pork preservation. Food Packag. Shelf Life 2020, 26, 100554. [CrossRef]

107. Woltman, G.R.; Liu, Y.; Quincy, R.B., III. Water Permeable Porous Layer Materials Treated with Surfactant-Modified Cyclodextrins. U.S. Patent 6,433,243 B1, 13 August 2002.

108. Carlucci, G.; Guarracino, M.; di Cintio, A. Cyclodextrin-Containing Odour Control Material for Absorbent Articles. EP 0894502A1, 3 February 1999.

109. Chiu, S.-H.; Chung, T.-W.; Giridhar, R.; Wu, W.-T. Immobilization of $\beta$-cyclodextrin in chitosan beads for separation of cholesterol from egg yolk. Food Res. Int. 2004, 37, 217-223. [CrossRef]

110. Dias, H.; Berbicz, F.; Pedrochi, F.; Baesso, M.; Matioli, G. Butter cholesterol removal using different complexation methods with beta-cyclodextrin, and the contribution of photoacoustic spectroscopy to the evaluation of the complex. Food Res. Int. 2010, 43, 1104-1110. [CrossRef]

111. Mortensen, A.; Aguilar, F.; Crebelli, R.; Domenico, A.D.; Dusemund, B.; Frutos, M.J.; Galtier, P.; Gott, D.; Remy, U.G.; Leblanc, J.C.; et al. Re-evaluation of $\beta$-cyclodextrin (E 459) as a food additive. EFSA J. 2016, 14, 4628. [CrossRef] 
112. European Union. Commission directive 2003/95/EC of 27 October 2003 amending Directive 96/77/EC laying down specific purity criteria on food additives other than colours and sweeteners. Off. J. Eur. Union 2003, L283/77, 71-77.

113. Fenyvesi, E.; Vikmon, M.; Szente, L. Cyclodextrins in Food Technology and Human Nutrition: Benefits and Limitations. Crit. Rev. Food Sci. Nutr. 2015, 56, 1981-2004. [CrossRef] 